\title{
MENCIPTAKAN LINGKUNGAN RELIGIOUS PADA LEMBAGA PENDIDIKAN ISLAM
}

\author{
Budi Harto \\ Program Studi Pendidikan Agama Islam, \\ Sekolah Tinggi Agama Islam Solok, Sumatera Barat
}

\begin{abstract}
The aims of this study were: 1) to figure out the way of creating religious atmosphere among teachers, 2) to figure out the way of creating religious atmosphere in terms of instructional materials, 3) to figure out the way of creating religious atmosphere in school environment where the educational process took place. To make sure that the students have Islamic characters (akhlaq) in primary education level by merely giving them understanding toward Islam were not effective. Conversely, familiarizing and modeling from teachers, parents, and Islamic environment gave better influence toward students' religious characters formation.
\end{abstract}

Kata kunci: pendidik, materi pelajaran integral, lingkungan sekolah

\section{PENDAHULUAN.}

$\mathrm{P}$ endidikan dan pembinaan keagamaan pada masa usia seolah dasar (SD) sangat penting bagi pertumbuhan dan perkembangan jiwa keagamaan pada anak. Pembinaan iman sejak dini, pembiasaan dengan lingkungan yang islami merupakan suatu usaha untuk menanamkan pengaruh agama pada jiwa mereka yang masih labil.

Pendidikan anak seusia sekolah dasar (SD), misalnya dalam hal pembentukan jiwa keagamaaan akan lebih mudah diberikan melalui pembiasaan, hal ini tanpa menyampingkan faktor pemahaman. Pembiasaan pada masa ini sangat kuat dalam membentuk karakter atau mempengaruhi tingkah laku anak. Pembentukan sikap, pembinaan moral dan kepribadian pada umumnya melalui pengalaman semenjak kecil, semua pengalaman yang dilalui tersebut meru- pakan unsur yang penting dalam pribadinya. Latihan-latihan keagamaan yang menyangkut akhlak dan ibadah sosial atau hubungan manusia dengan manusia, sesuai dengan ajaran agama, jauh lebih penting dari pada dengan penjelasan kata-kata. Latihan-latihan tersebut diberikan oleh guru atau orang tua melalui contoh praktek kehidupan sehari-hari.

Dewasa ini mendidik anak terutama pada pendidikan dasar perlu perhatian dan usaha yang sungguhsungguh karena pada usia ini segala sesuatu yang terjadi dilingkunganya sangat cepat diserap dan ditiru oleh sianak, dia belum mempunyai penalaran untuk memikirkan apakah tindakan tersebut benar atau salah yang jelas apapun yang terjadi dilingkungan sianak sangat cepat terekam dalam memori otak anak dan menjadi dasar bagi mereka untuk berbuat 
Oleh karena hal tersebut diatas untuk menghindari anak-anak didik dari lingkungan negatif yang akan berbahaya bagi perkembangannya lebih lanjut maka sangat penting untuk menciptakan situasi lingkungan anak didik dengan lingkungan religious, karena lingkungan tersebut sebagai dasar bagi anak dalam perkembangan keagamaan pada periode selanjutnya

Apabila masa dasar anak dioptimalkan dengan latihan amalan dan situasi agamis, untuk masa selanjutnya pendidik, guru disekolah, orang tua dirumah akan lebih mudah meneruskan ajaran agama yang diperoleh anak tersebut untuk diteruskan masa selanjutnya (tingkat sekolah lanjutan) karena jiwa dan kepribadian anak dari dasar sudah dibentuk dengan jiwa agama.

\section{PENCIPTAAN LINGKUNGAN ISLAMI PENDIDIKAN ISLAM}

Suasana religious adalah keadaan disekitar (lingkungan) yang bernuansa agamis. Sedangkan lembaga pendidikan Islam adalah suatu wadah tempat berlangsungnya proses pendidikan Islam. Lingkungan yang Islami menjadi ciri dari prinsip dasar konsep pendidikan Islam. Di bawah ini diuraikan hubungan lingkungan dengan suatu proses pendidikan Islam

Seperti diketahui bahwa suasana lingkungan atau pengaruh lingkungan sangat menentukan keberhasilan suatu pendidikan, apalagi untuk menanamkan nilai-nilai agama. Hal ini sesuai apa yang dikatakan oleh Kamarani Buseri bahwa: "Penanaman Iman tidak banyak merupakan hasil pengajaran. Yang besar pengaruhnya adalah lingkungan, yang berisi peneladanan dan pembiasaan. Lingkungan agamis akan berpengaruh besar terhadap siswa, sehingga mereka menjadi orang yang beragama" (Kamarani Buseri, 1997:28)
Menurut Athiyah al-Abrasyi: "Tidak ada seorangpun yang mengingkari adanya pengaruh lingkungan dalam pendidikan anak. Oleh karena itu sangatlah penting memperhatikan lingkungan sekolah di mana anak-anak didik. Untuk tujuan pendidikan keagamaan maka diperlukan adanya suasana keagamaan di sekolah. Dalam menerapkan suasana keagamaaan di sekolah ada beberapa aspek yang perlu diperhatikan, yaitu:guru, materi pelajaran dan lingkungan tempat sekolah (Abbudin Nata, 1997:132).

Lingkungan dalam hubungannya dengan pendidikan adalah segala sesuatu yang berada disekitar anak didik baik berupa benda-benda, peristiwa yang terjadi maupun kondisi masyarakat terutama yang dapat memberikan pengaruh kuat kepada anak, dan lingkungan di mana anak-anak bergaul. Di bawah ini akan dijelaskan aspek-aspek yang perlu diperhatikan dalam menciptakan suasana yang islami.

\section{Guru}

Guru merupakan suatu aspek penting dalam suatu proses pendidikan Islam. dan sangat berpengaruh banyak terhadap peserta didik. Oleh karena itu semua guru dalam pendidikan Islam harus senantiasa mencerminkan kepribadian yang Islami, fungsi dalam hal ini adalah sebagai tauladan yang baik yang akan mempengaruhi atau menciptakan suasana yang Islami di lingkungan peserta didik.

Tujuan utama dari pendidikan islam adalah membentuk akhlak manusia dari akhlak yang tidak baik kepada akhlak yang baik, Sesuai hadis nabi Muhammad saw "Sesungguhnya Aku diutus kepermukaan bumi ini adalah untuk memperbaiki akhlak manusia" dalam rangka membentuk akhlak tersebut tidak bisa hanya diperkaya dengan materi agama (akhlak) semata tetapi bagaimana pendidik mewariskan akhlak 
yang baik tersebut kepada anak didik. Sebelum akhlak yang baik tersebut diwariskan pada anak didik, terlebih dahulu pendidik harus memiliki dalam kepribadiannya, selanjutnya apa yang dimiliki tersebut dapat diwariskan kepada anak didik. "kita tidak dapat mengajarkan pada anak apa-apa yang kita ketahui dan kita ingini, tetapi kita hanya dapat mengajarkan dan mewariskan pada anak apa yang kita miliki.

Sesuatu yang harus dimiliki oleh pendidik islami adalah di samping mempunyai ilmu umum juga mempunyai ilmu agama dan mengamalkan ilmu tersebut dalam kehidupan sehari-hari seperti mempunyai sifat penyayang, penyabar, ramah, sopan, cinta sesama, suka membantu orang yang kesusahan dan akhlak baik lainnya. Sebelum sifatsifat ini diwariskan kepeserta didik, seorang pendidik haruslah memiliki sifat-sifat tersebut pada dirinya, sehingga siswa menjadikan akhlak guru tersebut sebagai pedoman dalam tingkah laku sehari-hari, hal ini secara tidak langsung kepribadian guru memantul (bias) pada kepribadian anak didik.

Tidak menyatunya amalan agama pada diri siswa adalah karena apa yang diajarkan oleh guru atau pendidik tentang materi agama tidak terdapat (tercermin) dalam tingkah laku guru di sekolah dan luar sekolah, sehingga muncul anggapan pada siswa bahwa ilmu tersebut hanya untuk diketahui bukan untuk diamalkan

Dalam lembaga pendidikan Islam, sebaiknya semua guru bersatu padu dalam menciptakan suasana lingkungan yang islami bagi peserta didik. Oleh karena itu semua guru yang terlibat dalam proses pendidikan harus mempunyai pengetahuan dan pemahaman agama yang cukup. Hal ini dapat dilakukan dengan pembinaan untuk guru tersebut secara berkelanjutan. Abdurrahman Mas'ud mengatakan: Bahwa guru yang berfungsi sebagai role model bagi peserta didik harus menjadi teladan bagi kehidupan sosial akademis siswa baik di dalam maupun di luar kelas. (Abdurrahman Mas'ud, 2003: 202) Guru harus memberi contoh dan komitmen dalam kegiatan-kegiatan akademis dan sosial keagamaan.

Tenaga pendidik (guru) merupakan factor penting dalam menciptakan suasana religious, seperti diungkapkan oleh Kamal Muhammad:

"Seorang guru seyogyanya mampu menjadi tauladan yang soleh, contoh tauladan yang baik bagi semua murid. Jika sang guru mampu menawan hati para anak didiknya, maka hampir dipastikan muridnya akan meniru tingkah lakunya (Kamal Muhammad, 1992: 66).

Jadi faktor guru dalam menciptakan suasana yang agamis pada dirinya sendiri sangatlah penting dalam rangka membentuk kepribadian anak didik sesuai dengan ajaran agama. Guru dapat dijadikan contoh oleh siswa dalam kebiasaan sehari-hari, sehingga apabila kebiasaan guru sesuai dengan nilai-nilai ajaran Islam, maka akan memantul dalam kepribadian siswa

\section{Materi Pelajaran}

Dalam sistem pendidikan Islam proses belajar-mengajar harus diwarnai oleh nuansa yang Islami pula. Setiap materi pelajaran harus selalu dihubungkan dengan ajaran Islam, terutama yang berkaitan dengan kekuasaan mutlak Allah SWT sebagai penguasa ilmu. Seperti halnya dengan mata pelajaran sejarah, bahwa ketika seorang guru menerangkan terjadinya revolusi prancis yang memproklamirkan hak azazi manusia, maka guru yang bersangkutan harus mampu menjelaskan tentang pandangan Islam tentang hak azazi manusia.

Seharusnya pendidik, berusaha memberikan materi pelajaran umum dengan mengaitkan dengan nilai agama ketika setiap kali mengajar. Seperti 
mengajar matematika. Pelajaran tersebut belum dirancang secara kusus tentang pengintegrasian dengan materi keagamaan akan tetapi hal tersebut dituntut pengetahuan dan kiat guru tersendiri untuk mengkondisikannya sesuai dengan agama. Seperti waktu proses belajarmengajar matematika dimulai. Guru berkata "dalam barisan shalat satu saf ada 25 orang, seandainya jumlah syaf 6 , berapa jumlahkah semua orang yang salat ?. "Shalat sendirian di rumah mendapat pahala satu kali lipat, sementara shalat berjamaah di Masjid mendapat pahala sebanyak 27 kali lipat. Berapakah pahala orang yang shalat secara berjamaah dalam lima waktu sehari semalam?.

Dari contoh di atas dapatlah dipahami bahwa guru berusaha menyatukan mata pelajaran matematika dengan nilai agama. Hal ini memberikan kesan di samping siswa belajar tentang matematika, siswa juga di berikan materi tentang pentingnya shalat secara berjamaah. Sesuatu yang dapat dipetik dari metode semacam ini bagi siswa adalah setiap mendapat materi pelajaran mereka menerima juga pelajaran yang berjiwa agama.

Dengan adanya model pengajaran semacam ini, guru dituntut untuk memperdalam ilmu pengetahuan umum di samping ilmu-ilmu keagamaan, sebab dalam menerapkan metode belajar seperti ini tidak dibuat kurikulum khusus, hanya saja dituntut kiat tersendiri bagi guru.

Dalam mata pelajaran Bahasa Indonesia, guru bahasa Indonesia, dalam mengajar murid-muridnya dapat juga mengaitkan dengan materi-materi agama misalnya:

"Sekarang kita belajar Bahasa Indonesia dengan topik membaca yang baik dan benar. Nah bacalah topik di bawah ini tentang penemuan mesin uap, mobil, dan kapal terbang. Setelah siswa selesai membaca bacaan tersebut, guru selanjutnya menjelaskan bahwa "ilmuilmu yang ditemukan tadi semuanya ditemukan oleh orang-orang non muslim, sebenarnya pada zaman dahulu banyak juga ilmuwan-ilmuwan Islam yang telah berjasa dalam menemukan berbagai macam di bidang IPTEK. Seperti al-Razi penemu tangga Nada, Ibnu Sina, kedokteran, al-Karizmi, ilmu matematika. Selanjutnya guru memberikan tugas kepada para siswa untuk mencari siapa-siapa saja tokoh-tokoh Islam zaman dahulu yang telah berjasa terhadap penemuan ilmu pengetahuan dan teknologi.

Dari paparan di atas jelaslah bahwa guru bahasa Indonesia tersebut berusaha untuk mengarahkan perhatian siswa pada ajaran agama dengan memunculkan tokoh-tokoh Islam yang telah berjasa terhadap perkembangan ilmu pengetahuan dan teknologi.

Hal yang sama juga diterapkan pada guru bidang studi IPA, dengan memberikan materi tentang:

"pembagian waktu "guru menjelaskan tentang perputaran bumi yang mengelilingi matahari. Pada akhir cerita guru tersebut, ia menceritakan kepada siswa tentang kebesaran Allah yang mampu membuat bumi berputar mengelilingi matahari" Sungguh maha kuatnya Allah yang setiap hari menggerakkan bumi untuk mengelilingi matahari, dengan adanya perputaran tersebut terjadilah empat musim yaitu musim semi, musim dingin, musim gugur dan musim panas. Kita sepatutnya berterima kasih kepada Allah yang telah menjadikan negara kita dua musim yaitu sup tropis kering dan hujan, dengan dua sup tropis ini tidak ada halangan yang berarti bagi kita untuk melakukan berbagai aktifitas sehari-hari. Sementara di Eropa, andai muncul musim salju mereka berbulan-bulan menunggu habisnya musim salju tersebut.sehingga 
membuat mereka beristiharat untuk melakukan berbagai macam kegiatan-kegiatan sehari-harinya. Oleh karena itu kita bersyukur yang mana Allah telah memberikan dua musim kepada kita dengan musim panas dan hujan yang mana andai datang dua musim tersebut tidak menghalangi kita untuk beraktifitas sebagaimana yang di dapati oleh negara lain yang bermusim dingin atau musim salju selama berbulanbulan.

Dari keterangan di atas dapat dipahami bahwa guru berusaha di samping menjelaskan pelajaran IPA, juga memberikan materi keagamaan dengan menceritakan tentang kebesaran Allah yang patut disyukuri.

Kamal Muhammad mengatakan: bahwa seorang guru yang sedang mengajarkan ilmu alam hendaknya menjelaskan kepada muridnya bahwa teori dan kaidah yang ada didalam ilmu alam itu sama sekali bukanlah ciptakaan orang Barat, namun dikutip atau diciplak atau dikembangkan dari catatan dan jurnal ilmiah para ilmuwan Muslim terdahulu. Ilmu kedokteran contohnya, ternyata masih dipelajari di berbagai universitas Eropa sampai abad ke- 18, bahkan teori Hitsam tentang mata dan penglihatan manusia masih di ajarkan disana sampai abad ke- 1 (1992:66)

Pada bagian lain Ismail Raji alFaruki menawarkan materi pendidikan yang Islami. Ia mengkritik perkembangan sains dan teknologi moderen yang dipisahkan dari ajaran Islam. Menurutnya pengembangan ilmu pengetahuan perlu kepada kerangka dan perspektif ajaran Islam. Perlu diadakan gerakan Islamisasi ilmu pengetahuan". Senada dengan itu Abudin Nata, mengatakan :bahwa pendidikan yang Islami harus dirancang berdasarkan konsep Tauhid dalam hubungannya dengan perkembangan ilmu pengetahuan. Tiada suatupun ilmu pengetahuan kecuali dikem- balikan kepada asalnya yaitu Allah SWT(Abbudin Nata:132)

Dari penjelasan di atas dapatlah disimpulkan bahwa seyogyanya guru selalu memberikan materi pelajaran umum dengan materi pelajaran agama di dalam melakukan proses belajar-mengajar. Dengan hal ini siswa tidak terlepas dari ajaran yang bersifat keagamaan. Sehingga akan menghilangkan kesempitan dalam mengembangkan aspek religious, selama ini sistem pendidikan yang ada terutama pendidikan Islam memperkecil batasan aspek religius, dengan tidak mengkombinasikan antara ilmu umum dengan ilmu yang bersifat keagamaan.

Bagaimana kiat guru sekolah menjadikan materi umum terintegrasi dengan ajaran Islam, hal ini dituntut kemampuan pendidik dalam mengembangkannya. Oleh karena itu, seorang pendidik, haruslah memahami Islam secara universal, atau harus ada kompetensi dan pemahaman keagamaan pada pendidik tersebut, dengan demikian guru-guru mengetahui bagaimana kiatnya menyatukan materi umum dengan nilai-nilai Islam.

Guru-guru seharusnya memiliki nilai spritual yang kopetensi yang memang telah disiapkan dan dikader dengan pemahaman Islam yang universal sehingga dengan pemahaman tersebut guru-guru mampu memberikan pada setiap materi umum dengan ajaran Islam.

Jika materi pendidikan umum selalu dikaitkan dengan konsep-konsep Islam, maka dapat diharapkan jiwa, mental, dan akhlak generasi Islam akan menjadi jiwa yang integral antara kehendak Rabbaniah dan kehendak Insaniah. Keadaan ini sekaligus akan dapat menghapus secara bertahap image yang sudah terlanjur berkembang di tengah-tengah kehidupan umat islam bahwa ada dikotomi antara pendidikan Islam dan pendidikan umum. 
Dengan adanya penyatuan (integral) setiap mata pelajaran dengan ajaran islam maka dengan sendirinya pemikiran siswa tidak terlepas dari nuansa keagamaan (tauhid) dengan ini aspek religious dari pemikiran akan terus dilatih dan diperkaya sehingga terciptalah anak didik atau lulusan yang berjiwa Islami, apaun bidang keahliannya yang ditekuninya.

\section{Lingkungan Sekolah}

Lingkungan sekolah merupakan tempat bangunan sekolah berdiri, di tempat itu juga para guru dan murid melaksanakan berbagai aktifitas belajar. Saling interaksi yang komplek antara guru sesama guru, murid sesama murid dan murid dengan guru juga terjadi di lingkungan sekolah. Secara langsung atau tidak suasana dari interaksi yang komplek itu akan sangat berpengaruh terhadap pembentukan kepribadian peserta didik

Dalam lingkungan sekolah segala tindakan, ucapan, guru dan termasuk pegawai, penjaga sekolah seharusnya menerapkan segala aturan (norma) yang telah ditetapkan bersama sehingga ditutup celah untuk dilihat oleh siswa segala ucapan, akhlak yang bertentangan dengan norma yang menjadi isi dari tujuan pendidikan yang telah ditetapkan bersama

Penciptaan suatu lingkungan yang bernuansa Islami adalah suatu kemestian dalam proses pembelajaran Islam. Setiap aktifitas yang ada atau yang akan dilaksanakan di lingkungan sekolah itu seyogyanya diformat sedemikian rupa sesuai dengan prinsip-prinsip ajaran Islam. Suasana itu diharapkan dapat memantul kepada seluruh kepribadian peserta didik.

Dalam usaha menciptakan suasana religious pada Lembaga Pendidikan Islam disekolah bagi peserta didik, akan lebih banyak dengan cara praktek ajaran Islam baik secara langsung oleh siswa maupun melalui apa yang dipraktekan oleh guru-guru, Dalam pelaksanaan praktek keagamaan tersebut dilakukan dalam dua lingkungan, yaitu lingkungan sekolah dan luar sekolah (rumah).

Praktek dilingkungan sekolah diterapkan ketika siswa mulai masuk gerbang dan berakhir ketika siswa mulai meninggalkan sekolah. Disekolah misalnya siswi diwajibkan memakai jilbab dan bagi siswa memakai celana panjang. Dalam praktek yang berhubungan dengan kehidupan sehari-hari, guru memberikan penjelasan dilokal, tentang pentingnya membiasakan akhlak yang baik, untuk memotifasi siswa melakukan halhal yang diperintah, guru menjelaskan tentang pahala yang diperoleh bila melakukan hal-hal yang baik serta ancaman dosa yang timbul bila melakukan sesuatu yang melanggar agama.

Berhubungan dengan perilaku sehari-hari siswa diharuskan berperilaku sesuai dengan ajaran Islam, seperti membiasakan membaca doa setiap masuk dan keluar dari WC. Memasuki WC harus didahulukan kaki kiri dan keluar melangkahkan kaki kanan, masuk kedalam masjid harus membaca doa, begitu juga bila keluar masjid. Sebelum dan sesudah makan diharuskan membaca doa, tidak boleh makan dan minum sambil berdiri, dan makan dengan tangan kanan.

Seluruh siswa sudah harus keluar dari kelas lebih awal kira-kira 10-20 menit sebelum masuk waktu sholat. Hal tersebut di maksudkan supaya siswa berwudhu dengan baik dan tertib. Ketika azan di kumandangkan siswa di bimbing untuk menjawab panggilan azan, membaca do'a sesudah azan secara berjamaah dan melaksanakan sholat sunat rawatib muakad dan ghairu muakad sebelum dan sesudah sholat wajib. Sesudah sholat berjamaah, siswa dan bersama dengan seluruh guru termasuk kepala sekolah, wakil, dan karyawan membaca tasbih dan do'a. pembacaan do'a tersebut di 
pimpin oleh seorang siswa yang telah di tunjuk sebelumnya.

Siswa diharuskan melakukan sholat dhuha setiap hari yang diberi waktu untuk melaksanakannya kira- kira 15 menit, dengan maksud agar siswa terbiasa melaksanakan sholat tersebut. Siswa juga dibiasakan membaca al mat surat (doa-doa yang biasa dibaca oleh Nabi dalam kehidupan sehari-hari) secara bersama- sama, siswa yang lakilaki dibimbing oleh guru laki- laki, dan siswi yang perempuan di bimbing oleh guru perempuan. Selain hal tersebut siswa juga di bina untuk menghafal alqur'an sehingga ada target- target tertentu yang harus dihafal di hafal oleh siswa, disamping menilai dan memperbaiki bacaan siswa mengenai tajwid alQur'an.

Untuk kegiatan di luar sekolah, setiap siswa diberi progaram khusus berupa amalan-amalan agama dan akhlak yang harus dikerjakan setiap harinya. Dalam hal ini siswa di beri buku panduan tentang sholat- sholat wajib yang harus di lakasanakan dan amalanamalan sunat yang di anjurkan, seperti sholat wajib yang harus di laksanakan dan amalan sunat yang di anjurkan seperti sholat wajib 5 kali sehari semalam, sholat sunnah seperti dhuha, tahajjud, hajat, memebaca al- qur'an, membaca alamat surat, membaca bukubuku yang islami, puasa sunnah, sholat jamaah dimesjid terdekat dengan rumah, muhasabah (eveluasi diri), berinfak, tidak melanggar perintah orang tua, olah raga, hafalan al-qur'an, membantu orang tua, ber do'a untuk oarang tua dan amalan-amalan baik lainnya. Kesemua amalan tersebut telah tertera dalam buku panduan. Tugas oarang tua adalah membubuhkan tanda tangan pada setiap kolom yang sesuai menurut apa yang diamalkan.

Sekali satu minggu buku panduan ibadah siswa tersebut di kumpulkan dan dicek oleh wali kelas yang bersangkutan.
Bagi siswa yang melaksanakan secara maksimal akan di beri penilain berupa reward yang baik, plus dan berpengaruh terhadap nilai rapor, sedangakan bagi siswa yang sedikit melaksanakan amalan-amalan yang telah di tentukan tersebut akan di proses selanjut oleh wali kelas. Dalam proses tersebut mengapa tidak melakukan amalan-amalan yang telah di tetapkan, apa penyebabnya dan kemudian guru/ wali kelas berusaha untuk mencarikan jalan keluar supaya hal yang sama tidak terulang lagi.

Dengan demikian tiga aspek penting yaitu guru, materi pelajaran dan lingkungan sekolah harus dirancang secara sistematis untuk mewujudkan suasana yang benar-benar Islami. Suasana ini akan menjadi warna dari keseharian peserta didik dimana mereka menimba ilmu pengetahuan. Jika suasana Islami juga dilanjutkan di dalam keluarga dan masyarakat, maka besar kemungkinan tujuan pendidikan Islam yang dicita-citakan akan tercapai secara maksimal.

\section{KESIMPULAN}

1. Mendidik anak didik menjadi manusia yang agamis tidaklah mudah, tidak bisa digantungkan hanya pada guru semata, akan tetapi hal ini sangat membutuhkan kerja sama semua elemen pendidikan yang bertanggungjawab terhadap keberhasilan peserta didik

2. Penciptaan suasana agamis pada siswa mengacu kepada aktifitas tenaga pendidik yang bernuansakan islam. Terutama dalam meningkatkan kualitas keimanan dan kuantitas amaliyah sehingga kebiasaan agamis yang dipraktekan guru di sekolah akan dapat memantul dan dicontoh anak didik

3. Dalam materi pelajaran, setiap guru menerangkan materi pelajaran harus dibubuhi nuangsa aga- 
misnya agar siswa mempunyai pemahaman apapun macam ilmu pengetahuan tidak terlepas dari kekuasaan Allah

4. Diharapkan sekolah lebih mengintensifkan komunikasi kepada orang tua siswa mengenai pentingnya lembaga keluarga sebagai salah satu pilar yang ikut me-

\section{DAFTAR RUJUKAN}

Al-Naquib M, al-Attas, 1990. Konsep Pendidikan Dalam Islam, Bandung: Mizan.

Arifin, M. 1996. Ilmu Pendidikan Islam, Jakarta:Grafindo Persada.

--------,1987. Kapita Selekta Pendidikan (Islam dan UMUM), Jakarta;Bumi Aksara

Arikunto, Suharsimi, 1990. Manajemen Pengajaran Secara Manusiawi, Rineka cipta

Abdullah, Saleh Abdurrahman, 1990. Teori-teori Pendidikan Berdasarkan al-Qur,an, Jakarta:Rineka Cipta , 1991. Pendidikan Islam Dalam Arus Dinamika Masyarakat, Suatu Pendekatan Filosofis Pedagogis, Psikososial dan Kultural, Jakarta: Golden Teraton Press,.

An-Nahlawi, Abdullah, 1995. Pendidikan Islam di Rumah Sekolah dan Masyarakat, Jakarta: Gema Insani Press

Bamawi, Imam, 1987. Segi-segi Pendidikan Islam, Surabaya:al-Ihklas,

Barnadib, Imam, 1994. Filsafat Pendidikan (Pengantar Mengenai Sistem dan Metode) Yokyakarta:Andi Opset

Darajat, Zakiah, 1986. Pendidikan Islam, Jakarta: Bumi Aksara nentukan keberhasilan pendidikan, terutama pendidikan agama.

5. Dan yang tidak kalah pentingnya adalah bagaimana menciptakan suasana lingkungan anak di sekolah maupun di luar sekolah agar tetap terjaga dengan amalan islami dan terhindar dari hal-hal yang akan merusak kehidupan anak.

,1995. Pendidikan Islam Dalam keluarga dan Sekolah, Bandung: Remaja Rosdakrya Ofset

Freud, Sigmund (terj. Kees Bertens), 1984. Memperkenalkan psiko Analisa, Jakarta:Grammedia

Fasli Jalal. 2001. Dedi Supriadi, Reformasi Pendidikan Dalam Kontek Otonomi Daerah, Yokyakarta: ADICIA Karya Nusa

Hasan, Fuad, 1997. Dasar-dasar Kependidikan, Jakarta:Rineka Cipta,

Hasbullah, 2000. Dasar-Dasar Ilmu Pendidikan, Jakarrta: Grafindo Persada, $\quad$ H. A. R Tilaar, Paradigma Baru Pendidikan Nasional, Jakarta:Rineka Cipta

Hamalik, Oemar, 1999. Kurikulum dan Pembelajaran, Jakarta: Bumi Aksara

J, Lexy Moleong, 1991. Metodologi Penelitian Kualitatif: Bandung: Remaja Rosdakarya,.

Jalaluddin, Teologi Pendidikan, Jakarta: Grafindo Persada

Kamus Besar Bahasa Indonesia:Balai Pustaka

Langgulung, Hasan, 2002. Peralihan Paradigma Dalam Pendidikan Islam dan Sains, Sosial Jakarta: Media Pratama, , Manusia dan Pendidikan, Suatu Analisis Psikologi dan Pendidikan. 
1996. Teori-teori Kesehatan Menta.l Media Informasi Cendikia Muslim, Adzkia:Padang,.

Mulyono, Bambang, 1984. Pendekatan Analisis Kenakalan Remaja dan Penanggulangannya,Yokyakarta: Kanisius

Muhammad, Kamal, 1992. Manajemen Pendidikan Islam, Jakarta:Fikahari Aneska

Mahmud, Dimyati, 1990. Psikologi Pendidikan, Suatu Pendekatan Praktis, Yokyakarta:BPFE

Nata Habuddin, 2003. Manajemen Pendidikan, Jakarta:Kencana

Nasih, Abdullah Ulwan, 2003. Pendidikan Anak Dalam Islam, Jakarta:Amani ,1997. Filsafat Pendidikan Islam, I Jakarta; Logos ,2003. Manajemen Pendidikan Islam, Mengatasi Kelemhan Pendidikan Islam di Indonesia, Jakarta:Kencana

Nizar, Syamsul, 2000. Dasar-Dasar Pemikiran Pendidikan Islam (sebuah Pengantar Pendidikan Islam), IAIN IB Press, 1999. Peserta Didik Dalam Pendidikan Islam, Pengantar Filsafat Pendidikan Islam:IAIN IB Press

Nizar, Hayati, 1998. Kajian Evaluatif Terhadap Pendidikan Agama Islam di sekolah Lanjutan dan Pokok-Pokok Pekerjaan Untuk Pelaksanaannya Ke depan,

Indek

guru, 149, 190, 191, 192, 193, 194, 195, 196

integral, 149, 194

materi, 149, 190, 191, 192, 193, 194, 195,196
Makalah Disampaikan Dalam seminar sehari Di Batusangkar,

Nasution, S. 1992. Metode Penelitian Naturalistik, Bandung:Transito, 1982. Metode Research, Penulisan Ilmiah, Bandung:Jemmars

Ramayulis, 2002. Ilmu Pendidikan ISlam, Jakarta:Kalam Mulia

Sani, Abdul, 1998. Lintasan Sejarah Pemikiran dan Perkembangan Dalam Islam:Jakarta:Grafindo

Sihombing, Umberto, 1999. Pendidikan Luar Sekolah, Kini dan Masa Depan, Konsep Kiat dan Pelaksanaannya, Jakarta

Soelaiman, Joesoef, 1992. Konsep Dasar Pendidikan Luar Sekolah, Jakarta: Bumi Aksara

Yonna S. Lincoln dan Egon Quba, 1985. Naturalistic Inquiry Bravely Hills:Sage Pulicasion

Mastuhu, 1999. Dinamika Sistem Pendidikan Pesantren, Suatu Kajian Tentang Unsur dan Nilai Sistem Pendidikan Pesantren, Jakarta: INIS

Zaini, Syahirman, 1986. Prinsip-prinsip Dasar Konsepsi Pendidikan Islam, Jakarta:Kalam Mulia

Zuahiri, dkk, Sejarah Pendidikan Islam, akarta: Bumi Aksara: Depag

, 2002. Pentingnya Pendidikan Islam Sejak Dini, Jakarta: A.h. Ba' adillah Press

pendidik, 149, 190, 191, 192, 193, 196

sekolah, 149, 190, 191, 193, 194, 195 ,

196, 197

Siswa, 195 